CLINICAL STUDY

\title{
Increased adipose tissue secretion of interleukin-6, but not of leptin, plasminogen activator inhibitor-1 or tumour necrosis factor alpha, in Graves' hyperthyroidism
}

\author{
Hans Wahrenberg, Anders Wennlund and Johan Hoffstedt \\ Department of Medicine, Karolinska Institutet, Huddinge University Hospital, Sweden \\ (Correspondence should be addressed to J Hoffstedt, M61, CME, Karolinska Institutet, Huddinge University Hospital, 14186 Stockholm, Sweden; \\ Email: johan.hoffstedt@medhs.ki.se)
}

\begin{abstract}
Objective: This study was designed to investigate adipose tissue secretion of interleukin-6 (IL-6), leptin, tumour necrosis factor alpha (TNF- $\alpha$ ) and plasminogen activator inhibitor-1 (PAI-1) in Graves' hyperthyroidism.

Design: We studied 10 patients before and during (after 8 weeks) anti-thyroid treatment for Graves' hyperthyroidism and 16 healthy, euthyroid control subjects.

Methods: Plasma levels of thyroid hormones and serum/plasma levels of IL-6, leptin, TNF- $\alpha$ and PAI-1 were analysed. Subcutaneous fat biopsies were taken for subsequent measurement of IL-6, leptin, TNF- $\alpha$ and PAI-1 protein secretion.

Results: In patients with Graves' disease, the anti-thyroid treatment resulted in significant reductions of plasma thyroxine and triiodothyronine levels. No differences in serum concentration or adipose tissue secretion of leptin or TNF- $\alpha$ were observed either before, as compared with during, anti-thyroid treatment, or in comparison with euthyroid controls. In contrast, plasma PAI-1 activity, but not adipose tissue secretion of PAI-1, was increased both in Graves' disease before as compared with during anti-thyroid treatment $(P=0.01)$ and in thyrotoxic patients compared with euthyroid controls $(P=$ $0.0001)$. Finally, adipose secretion of IL- 6 was increased both before ( 8 -fold, $P=0.001$ ) and during (6-fold, $P<0.0001$ ) treatment as compared with control subjects. Accordingly, serum concentration of IL-6 was also increased by about $50 \%$ in thyrotoxic patients as compared with healthy controls $(P=0.03)$.

Conclusions: In Graves' hyperthyroidism regardless of thyroid status, adipose tissue secretion of IL-6, but not of leptin, TNF- $\alpha$ or PAI-1, is markedly increased in comparison with euthyroid controls. This suggests that autoimmune thyroidal disorder may regulate adipose tissue release of IL-6.
\end{abstract}

European Journal of Endocrinology 146 607-611

\section{Introduction}

Human adipose tissue secretes a number of proteins among which leptin, tumour necrosis factor alpha (TNF- $\alpha)$, plasminogen activator inhibitor-1 (PAI-1) and interleukin-6 (IL-6) have all been found to act as auto-, para- or endocrine modulators of organ function (1). Leptin has a key role in body weight regulation by serving as an adipose satiety signal to the brain thereby influencing food intake and energy expenditure in a negative feedback loop (2). Besides their potent proinflammatory effects in host defence, both TNF- $\alpha$ and IL-6 have been implicated in regulating insulin signalling and lipid metabolism in peripheral tissues (1) whereas PAI-1, via modification of the fibrinolytic system, has a pathogenic role in atherothrombosis (3).
Although various conditions including obesity influence adipose tissue expression of leptin, TNF- $\alpha$, IL- 6 and PAI-1 (1), the hormonal regulation of protein release from adipose tissue has been only partly elucidated. Insulin and glucocorticoids stimulate adipose tissue release of leptin, whereas catecholamines have an opposite effect (4). Adipose tissue secretion of IL-6 is reduced after glucocorticoid incubation, but is unaffected by insulin (5). Thyroid hormones have marked effects on adipose lipid metabolism both in vivo (6) and in vitro (7). However, it is not known whether autoimmune thyroidal dysfunction plays a role in regulating protein secretion from human adipose tissue. In the present study, we examined the serum concentrations and abdominal subcutaneous adipose tissue release of IL-6, leptin, TNF- $\alpha$ and PAI-1 
in 10 patients before and during treatment for Graves' hyperthyroidism as well as in 16 healthy, euthyroid control subjects.

\section{Materials and methods}

\section{Subjects}

The study group consisted of ten female patients who were admitted to the Huddinge University Hospital's Department of Endocrinology from Primary Health Care units for treatment of Graves' hyperthyroidism. The patients were investigated before treatment was initiated and when they were found to be clinically euthyroid. All subjects were treated and clinically examined by the same investigators throughout the study ( $\mathrm{H}, \mathrm{HW}, \mathrm{AW})$. Except for the current disease, all subjects were previously healthy and were not on any medication. All patients had a history of 2-6 months of symptoms associated with hyperthyroidism. As a control group, 16 non-obese females were included after local recruitment. These subjects were all healthy with no signs of clinical thyroid disease and were free of medication.

All subjects were investigated in the morning after an overnight fast. Height and weight were measured and body fat content (percentage) was determined by bioimpedance (Model TBF 305, Tanika, Japan). A venous blood sample was obtained for the measurement of thyroid hormone levels at the Hospital's routine chemistry laboratory. Measures were made for thyroidstimulating hormone (TSH) (patients and controls) and the free plasma values of thyroxine $\left(\mathrm{T}_{4}\right)$ and triiodothyronine (patients). In patients, blood samples were also taken to analyse plasma levels of thyroid receptor stimulating antibodies (TRAb), which are characteristic of Graves' disease, using a method for percentage inhibition of binding. These measures were made at the Hospital's routine immunology laboratory. Serum concentrations of IL- 6 and TNF- $\alpha$ were measured using an enzyme-linked immunosorbent assay (ELISA, HSTA 50; R\&D Systems, London, UK) and a radioimmunoassay kit was used for the measurement of serum leptin (Linco, St Charles, MO, USA). Plasma PAI activity was analysed by ELISA (TintELIZE PAI-1, Biopool, Umeå, Sweden). Finally, a subcutaneous fat biopsy $(0.5-1.0 \mathrm{~g})$ was obtained from the umbilical region under local anaesthesia.

After the investigation, antithyroid treatment was initiated in the patients with Graves' disease and was continued throughout the study using $30 \mathrm{mg}$ thiamazol per day. The patients underwent clinical control at four-week intervals. All of them responded to the treatment with diminishing symptoms of hyperthyroidism and were re-investigated as soon as they were clinically euthyroid. However, the treatment was not aimed to achieve fully normalized levels of $\mathrm{TSH}$ and $\mathrm{T}_{4}$. In order to avoid any risk of hypothyroidism, which may increase the risk of endocrine ophthalmopathy, a block and replacement therapy was used (8). Therefore, after 4 weeks of treatment with thiamazol, $0.1 \mathrm{mg}$ thyroxine daily was added. None of the subjects received $\beta$-adrenoceptor blocking agents. The subjects were investigated for a second time when they had reached a clinically euthyroid state after 8-37 weeks of treatment. At this time, all measurements described above, including the fat biopsy, were repeated. The reason for the large interindividual variation between biopsies was due to the variation in relief of thyrotoxic symptoms. The study was approved by the ethics committe of Huddinge Hospital and all subjects gave informed consent to participate.

\section{Adipose tissue secretion of IL-6, leptin, PAI-1 and TNF- $\alpha$}

The adipose tissue was cut into small pieces (10$25 \mathrm{mg})$ and then incubated at $37^{\circ} \mathrm{C}(3.0 \mathrm{ml}$ medium/ $300 \mathrm{mg}$ tissue) in a medium consisting of sterile Krebs-Ringer phosphate buffer ( $\mathrm{pH} 7.4)$, endotoxinfree bovine serum albumin $(4 \mathrm{~g} / 100 \mathrm{ml})$ and glucose $(1 \mathrm{mg} / \mathrm{ml})$, with air as the gas phase. After a 2 -h incubation, a 1-ml aliquot of medium was removed and stored at $-70{ }^{\circ} \mathrm{C}$ for subsequent analysis of IL- 6 , leptin, PAI-1 and TNF- $\alpha$. These analyses were carried out using an enzyme-linked immunosorbent assay for PAI-1 (ELISA, TintELIZE PAI-1, Biopool), a radioimmunoassay kit for leptin (Linco) and ELISAs for IL-6 and TNF- $\alpha$ (HSTA 50; R\&D Systems).

\section{Statistical analysis}

Values are given as means \pm standard error of the mean (S.E.m.). Students' paired or unpaired $t$-tests were used for statistical comparisons.

\section{Results}

In all patients, plasma levels of TRAb were increased as a sign of Graves' disease. Table 1 shows the clinical characteristics of patients with Graves' hyperthyroidism before and during anti-thyroid treatment as well as those of controls. In all patients, the anti-thyroid treatment resulted in a significant reduction of plasma thyroxine and triiodothyronine levels. Except for one patient $(\mathrm{TSH}=6.7)$, TSH values were still at a low level at the time of the second investigation. Furthermore, in all patients clinical signs of hyperthyroidism diminished and body mass index (BMI) and percentage body fat increased as a result of anti-thyroid treatment. As compared with controls, no difference in age, BMI or percentage body fat was found. However, as expected a significant difference in TSH levels between patients and controls was observed. 
Table 1 Clinical characteristics of patients (Graves' disease) before and during treatment and of controls. Values are means \pm S.E.M.

\begin{tabular}{|c|c|c|c|c|c|}
\hline & \multicolumn{2}{|c|}{ Patients } & \multirow[b]{2}{*}{$\begin{array}{c}\text { Controls }(C) \\
(n=16)\end{array}$} & \multirow[b]{2}{*}{$\begin{array}{l}P \text { value } \\
A \text { vs } B^{\star}\end{array}$} & \multirow[b]{2}{*}{$\begin{array}{l}P \text { value } \\
A \text { vs } C^{* *}\end{array}$} \\
\hline & $\begin{array}{l}\text { Before treatment }(\mathrm{A}) \\
\qquad(n=10)\end{array}$ & $\begin{array}{l}\text { During treatment }(\mathrm{B}) \\
\qquad(n=10)\end{array}$ & & & \\
\hline Age (years) & $38 \pm 4$ & & $34 \pm 1$ & & 0.29 \\
\hline $\mathrm{BMl}\left(\mathrm{kg} / \mathrm{m}^{2}\right)$ & $24.0 \pm 1.6$ & $24.8 \pm 1.5$ & $23.7 \pm 0.5$ & 0.003 & 0.80 \\
\hline Body fat (\%) & $32.6 \pm 4.0$ & $37.4 \pm 3.9$ & $33.4 \pm 1.3$ & 0.0009 & 0.83 \\
\hline TSH $(\mathrm{mU} / \mathrm{l}, 0.3-5.0)^{\dagger}$ & $<0.03$ & $0.70 \pm 0.67$ & $2.00 \pm 0.25$ & 0.34 & $<0.0001$ \\
\hline Thyroxine $(\mathrm{pmol} / \mathrm{l}, 8-20)^{\dagger}$ & $61.4 \pm 5.9$ & $17.4 \pm 1.4$ & & $<0.0001$ & \\
\hline Triiodothyronine $(\mathrm{pmol} / \mathrm{l},<7.8)^{\dagger}$ & $38.1 \pm 6.0$ & $5.8 \pm 0.7$ & & 0.003 & \\
\hline
\end{tabular}

Comparisons were made using Student's paired $\left({ }^{*}\right)$ or unpaired $\left({ }^{* *}\right) t$-tests.

${ }^{\dagger}$ Values given in parentheses are euthyroid values.

Serum concentrations of IL-6, leptin and TNF- $\alpha$ and plasma activity of PAI-1 in patients before and during anti-thyroid treatment and in controls are shown in Table 2. No differences in serum levels of leptin or TNF- $\alpha$ were found either before as compared with during anti-thyroid treatment or in patients compared with controls. In contrast, plasma activity of PAI-1 was clearly influenced by thyroid status. In patients, the PAI-1 activity was more than twice as high before as compared with during treatment. Furthermore, in the control group the PAI-1 value was (almost) only $10 \%$ of that in untreated patients. With respect to serum concentration of IL-6, no effect of anti-thyroid treatment was found. However, as compared with controls, serum values of IL- 6 in untreated patients were increased by about $50 \%$.

The effect of anti-thyroid medication on adipose tissue secretion of IL-6, leptin, PAI-1 and TNF- $\alpha$ is shown in Table 3. No difference in secretion rate of any of these proteins was found before as compared with during anti-thyroid treatment. Furthermore, adipose secretion rates of leptin, PAI- 1 and TNF- $\alpha$ did not differ between patients with Graves' disease and healthy subjects. In contrast, adipose tissue secretion of IL-6 was increased almost 8-fold in patients with Graves' disease as compared with the control group (Fig. 1). A significant increase was still found when comparing values of patients with Graves' disease during treatment with those of control subjects $(P<$ 0.0001).
We also investigated whether adipose tissue release of IL-6 was correlated to various parameters. However, no correlations were found between IL-6 adipose release and plasma concentrations of thyroxine, triiodothyronine, TRAb or serum levels of IL-6 (data not shown).

\section{Discussion}

The present study was designed to investigate the putative role of autoimmune hyperthyroidism in regulating protein secretion from human adipose tissue. No difference in the release of leptin, TNF- $\alpha$ or PAI-1 from subcutaneous adipose tissue was found in patients with Graves' hyperthyroidism before, as compared with during, anti-thyroid treatment or in comparison with euthyroid controls. The adipose tissue secretion rate of IL- 6 was also unaffected by anti-thyroid treatment. However, adipose release of IL-6 was markedly increased in patients with Graves' disease both before and during treatment, as compared with control subjects.

Previous studies regarding the effect of thyroid status on levels of leptin, TNF- $\alpha$ and PAI-1 in man have primarily focused on serum measurements. In hyperthyroidism, increased $(9-11)$, decreased $(12-16)$ as well as unaffected $(17-20)$ serum levels of leptin have been observed, whereas unaltered $(10,13,17$, $18)$ or increased $(11,14,18,20)$ levels are reported in hypothyroidism. A gender-related regulation of

Table 2 Serum concentrations of IL-6, leptin and TNF- $\alpha$ and plasma activity of PAI-1 in Graves' disease before and during treatment, and in controls. Values are means \pm S.E.M.

\begin{tabular}{|c|c|c|c|c|c|}
\hline & \multicolumn{2}{|c|}{ Patients } & \multirow[b]{2}{*}{$\begin{array}{c}\text { Controls }(C) \\
\quad(n=16)\end{array}$} & \multirow[b]{2}{*}{$\begin{array}{l}P \text { value } \\
A \text { vs } B^{\star}\end{array}$} & \multirow[b]{2}{*}{$\begin{array}{l}P \text { value } \\
A \text { vs } C^{\star *}\end{array}$} \\
\hline & $\begin{array}{l}\text { Before treatment }(\mathrm{A}) \\
\qquad(n=10)\end{array}$ & $\begin{array}{l}\text { During treatment }(\mathrm{B}) \\
\qquad(n=10)\end{array}$ & & & \\
\hline IL-6 & $4.1 \pm 0.7$ & $4.1 \pm 0.8$ & $2.8 \pm 0.1$ & 0.98 & 0.03 \\
\hline Leptin & $16 \pm 5$ & $20 \pm 5$ & $10 \pm 1$ & 0.81 & 0.08 \\
\hline PAl-1 & $30 \pm 7$ & $12 \pm 8$ & $4 \pm 1$ & 0.01 & 0.0001 \\
\hline TNF- $\alpha$ & $3.2 \pm 0.3$ & $3.7 \pm 0.5$ & $3.2 \pm 0.8$ & 0.08 & 0.98 \\
\hline
\end{tabular}

Comparisons were made using Student's paired $\left({ }^{\star}\right)$ or unpaired $\left({ }^{\star *}\right) t$-tests. 
Table 3 Adipose tissue secretion (ng/g triglycerides) of IL-6, leptin, PAI-1 and TNF- $\alpha$ in Graves' disease before and during treatment, and in controls. Values are means \pm S.E.M.

\begin{tabular}{lccccc}
\hline & \multicolumn{2}{c}{ Patients } & & & \\
\cline { 2 - 5 } & $\begin{array}{c}\text { Before treatment }(\mathrm{A}) \\
(n=10)\end{array}$ & $\begin{array}{c}\text { During treatment }(\mathrm{B}) \\
(n=10)\end{array}$ & $\begin{array}{c}\text { Controls }(\mathrm{C}) \\
(n=16)\end{array}$ & $\begin{array}{c}\boldsymbol{P} \text { value } \\
\mathbf{A} \text { vs B* }\end{array}$ & $\begin{array}{c}\boldsymbol{P} \text { value } \\
\mathbf{A} \text { vs C** }\end{array}$ \\
\hline IL-6 & $8.2 \pm 2.4$ & $6.0 \pm 0.9$ & $1.1 \pm 0.4$ & 0.26 & 0.001 \\
Leptin & $212 \pm 35$ & $172 \pm 34$ & $229 \pm 53$ & 0.32 & 0.82 \\
PAl-1 & $27.4 \pm 8.7$ & $24.1 \pm 3.6$ & $23.2 \pm 7.0$ & 0.70 & 0.71 \\
TNF- $\alpha$ & $0.76 \pm 0.26$ & $0.68 \pm 0.18$ & $0.77 \pm 0.16$ & 0.83 & 0.96 \\
\hline
\end{tabular}

Comparisons were made using Student's paired $\left({ }^{\star}\right)$ or unpaired $\left({ }^{\star \star}\right) t$-tests.

leptin in Graves' disease has also been reported (21). Except in one study (22), no effect of thyroid status on serum levels of TNF- $\alpha$ has been demonstrated (23-26). Only a few studies on serum PAI-1 levels have been presented showing an increased level in hyperthyroidism (27) and a decreased level in severe hypothyroidism (28). Taken together with the data on both serum and adipose tissue secretion concentrations in this study, it can be concluded that thyroid status, at least in the case of hyperthyroidism, plays a minor role in the hormonal regulation of leptin and TNF- $\alpha$. In contrast, plasma activity of PAI-1 was markedly increased in hyperthyroidism as measured both as an effect of antithyroid treatment and as compared with euthyroid controls. However, adipose tissue release of PAI-1 was not influenced by thyroid status, which suggests that the observed increase in plasma PAI-1 activity is derived from tissues or cells of non-adipose origin.

With respect to IL-6, several studies are in agreement with the present results showing an increased serum

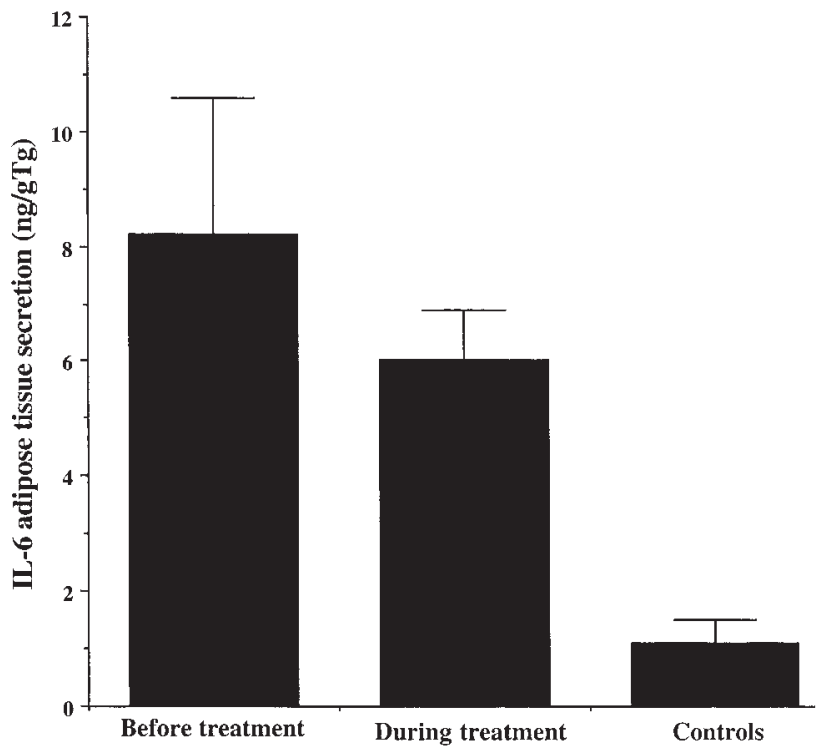

Figure 1 Adipose tissue secretion levels of IL-6 in Graves' hyperthyroid patients before and during treatment, and in euthyroid controls. Values are means \pm S.E.M. Tg, triglyceride. level in hyperthyroidism as compared with euthyroid control subjects $(22-24,29,30)$, whereas no effect has been found in two studies $(25,26)$. Given the results of the present study, an increased release of IL-6 from adipose tissue may be of pathophysiological importance in regulating the plasma levels of the cytokine in human hyperthyroidism. Based on in vivo experiments, it has been estimated that approximately $25 \%$ of the systemic levels of IL- 6 originate from subcutaneous adipose tissue (31). Consequently, nonadipose tissue or cells have a major influence on IL-6 production, which may explain why we could not detect any correlation between serum concentration and adipose release of IL-6 in this relatively small study sample. It should also be noted that several kinds of cells within adipose tissue, including mononuclear blood cells, fibroblasts and endothelial cells, may be responsible for secreting IL-6, since isolated adipocytes account for only $10 \%$ of the total tissue release of IL-6 (5).

Whether the observed increase in adipose tissue release of IL-6 in Graves' disease is due to a direct effect of thyroid hormones or can be explained by factors related to the autoimmune nature of the disease is unclear. The fact that all patients were clinically euthyroid, and that thyroid hormone levels normalised by the time of the second fat biopsy, speaks in favour of the latter explanation. Furthermore, we found no difference in either serum concentrations or adipose release of IL- 6 before as compared with during treatment, whereas both adipose and serum IL-6 levels were higher in untreated patients as compared with controls. However, a prolonged effect of thyroid hormone excess still present after eight or more weeks of anti-thyroid treatment cannot be excluded. Serum concentrations of IL-6 after treatment for Graves' disease have been shown to be both unaltered $(23,30)$ or declined $(22$, 24). Moreover, increased serum levels of IL-6 have also been found in non-autoimmune thyrotoxicosis $(22,24)$.

In conclusion, no difference in adipose tissue secretion of leptin, TNF- $\alpha$ or PAI-1 was found in patients with Graves' hyperthyroidism either before, as compared with during, anti-thyroid treatment or in comparison with euthyroid controls. In contrast, 
adipose release as well as serum concentrations of IL-6 were increased in Graves' disease, both before and during anti-thyroid treatment as compared with control subjects. The results suggest a role of autoimmune thyroidal dysfunction in regulating adipose tissue secretion of IL- 6 and partly contributing to the increased circulating levels of IL-6.

\section{Acknowledgements}

The skilful technical assistance of Eva Sjölin and Kerstin Wåhlén is greatly appreciated. This study was supported by grants from the Foundation of Thuring and the Swedish Society of Medicine.

\section{References}

1 Mohamed-Ali V, Pinkney JH \& Coppack SW. Adipose tissue as an endocrine and paracrine organ. International Journal of Obesity Related Metabolic Disorders 199822 1145-1158.

2 Huang L \& Cai L. Leptin: a multifunctional hormone. Cell Research $20001081-92$.

3 Hamsten A \& Eriksson P. Fibrinolysis and atherosclerosis. Bailliere's Clinical Haematology 19958 345-363.

4 Fried SK, Ricci MR, Russell CD \& Laferrère B. Regulation of leptin production in humans. Journal of Nutrition $2000 \mathbf{1 3 0}$ 3127S-3131S

5 Fried SK, Bunkin DA \& Greenberg AS. Omental and subcutaneous adipose tissues of obese subjects release interleukin-6: depot difference and regulation by glucocorticoid. Journal of Clinical Endocrinology and Metabolism $1998 \mathbf{8 3}$ 847-850.

6 Hagenfeldt L, Wennlund A, Felig P \& Wahren J. Turnover and splanchnic metabolism of free fatty acids in hyperthyroid subjects. Journal of Clinical Investigation 198167 1672-1677.

7 Arner P, Wennlund A \& Östman J. Regulation of lipolysis by human adipose tissue in hyperthyroidism. Journal of Clinical Endocrinology and Metabolism 197948 415-419.

8 Tallstedt L, Lundell G, Törring O, Wallin G, Ljunggren JG, Blomgren $\mathrm{H}$ et al. Occurence of ophthalmopathy after treatment for Graves' hyperthyroidism. The thyroid study group. New England Journal of Medicine 1992326 1733-1738.

9 Nakamura T, Nagasaka S, Ishikawa S, Hayashi H, Saito T, Kusaka I et al. Association of hyperthyroidism with serum leptin levels. Metabolism 200049 1285-1288.

10 Ozata M, Ozisik G, Bingol N, Corakci A \& Gundogan MA. The effect of thyroid status on plasma leptin levels in women. Journal of Endocrinological Investigation 199821 337-341.

11 Chen MD, Song YM, Tsou CT, Lin WH \& Sheu WH. Leptin concentration and the $\mathrm{Zn} / \mathrm{Cu}$ ratio in plasma in women with thyroid disorder. Biological Trace Element Research 200075 99-105.

12 Pinkney JH, Goodrick SJ, Katz J, Johnson AB, Lightman SL, Coppack SW et al. Leptin and the pituitary-thyroid axis: a comparative study in lean, obese, hypothyroid and hyperthyroid subjects. Clinical Endocrinology 199849 583-588.

13 Miyakawa M, Tsushima T, Murakami H, Isozaki O \& Takano K. Serum leptin levels and bioelectrical impedance assessment of body composition in patients with Graves' disease and hypothyroidism. Endocrine Journal 199946 665-673.

14 Pinkney JH, Goodrick SJ, Katz JR, Johnson AB, Lightman SL, Coppack SW et al. Thyroid and sympathetic influences on plasma leptin in hypothyroidism and hyperthyroidism. International Journal of Obesity Related Metabolic Disorders 200024 (Suppl 2) S165-S166.

15 Zimmermann-Belsing T, Dreyer M, Holst JJ \& Feldt-Rasmussen U. The relationship between the serum leptin concentrations of thyrotoxic patients during treatment and their total fat mass is different from that of normal subjects. Clinical Endocrinology $199849589-595$.

16 Obermayer-Pietsch BM, Fruhauf GE, Lipp RW, Sendlhofer G \& Pieber TR. Dissociation of leptin and body-weight in hyperthyroid patients after radioiodine treatment. International Journal of Obesity Related Metabolic Disorders 200125 115-120.

17 Corbetta S, Englaro P, Giambona S, Persani L, Blum WF \& BeckPeccoz P. Lack of effects of circulating thyroid hormone levels on serum leptin concentrations. European Journal of Endocrinology $1997137659-663$.

18 Sesmilo G, Casamitjana R, Halperin I, Gomis R \& Vilardell E. Role of thyroid hormones on serum leptin levels. European Journal of Endocrinology $1998139428-430$.

19 Mantzoros CS, Rosen HN, Greenspan SL, Flier JS \& Moses AC. Short-term hyperthyroidism has no effect on leptin levels in man. Journal of Clinical Endocrinology and Metabolism 199782 497-499.

20 Leonhardt U, Ritzel U, Schäfer G, Becker W \& Ramadori G. Serum leptin levels in hypo- and hyperthyroidism. Journal of Endocrinology $199815775-79$.

21 Miyakawa M, Tsushima T, Murakami H, Isozaki O \& Takano K. Serum leptin levels and bioelectrical impedance assessment of body composition in patients with Graves' disease and hypothyroidism. Endocrine Journal 199946 665-673.

22 Celik I, Akalin S \& Erbas T. Serum levels of interleukin 6 and tumour necrosis factor alpha in hyperthyroid patients before and after propylthiouracil treatment. European Journal of Endocrinology $1995132668-672$.

23 Salvi M, Pedrazzoni M, Girasole G, Giuliani N, Minelli R, Wall JR et al. Serum concentrations of proinflammatory cytokines in Graves' disease: effect of treatment, thyroid function, ophthalmopathy and cigarette smoking. European Journal of Endocrinology $2000143197-202$.

24 Siddiqi A, Monson JP, Wood DF, Besser GM \& Burrin JM. Serum cytokines in thyrotoxicosis. Journal of Clinical Endocrinology and Metabolism 199984 435-439.

25 Burggraaf J, Lalezari S, Emeis JJ, Vischer UM, de Meyer PH, Pijl H et al. Endothelial function in patients with hyperthyroidism before and after treatment with propranolol and thiamazol. Thyroid $200111153-160$.

26 Komorowski J, Jankiewicz J, Robak T, Blasinska-Morawiec M \& Stepien H. Cytokine serum levels as the markers of thyroid activation in Graves' disease. Immunology Letters 199860 143-148.

27 Li Y, Chen H, Tan J, Wang X, Liang H \& Sun X. Impaired release of tissue plasminogen activator from the endothelium in Graves' disease - indicator of endothelial dysfunction and reduced fibrinolytic capacity. European Journal of Clinical Investigation 1998 28 1050-1054.

28 Chadarevian R, Bruckert E, Leenhardt L, Giral P, Ankri A \& Turpin G. Components of the fibrinolytic system are differently altered in moderate and severe hypothyroidism. Journal of Clinical Endocrinology and Metabolism 200186 732-737.

29 Lakatos P, Foldes J, Horvath C, Kiss L, Tatrai A, Takacs I et al. Serum interleukin-6 and bone metabolism in patients with thyroid function disorders. Journal of Clinical Endocrinology and Metabolism 199782 78-81.

30 Salvi M, Girasole G, Pedrazzoni M, Passeri M, Giuliani N, Minelli R et al. Increased serum concentrations of interleukin-6 (IL-6) and soluble IL-6 receptor in patients with Graves' disease. Journal of Clinical Endocrinology and Metabolism 199681 2976-2979.

31 Mohamed-Ali V, Goodrick S, Rawesh A, Katz DR, Miles JM, Yudkin JS et al. Subcutaneous adipose tissue releases interleukin-6, but not tumor necrosis factor-alpha, in vivo. Journal of Clinical Endocrinology and Metabolism 199782 4196-4200.

Received 15 October 2001

Accepted 30 January 2002 